\title{
Pb, CD ANd Cu Distribution And MOBILITY IN MARINE SEDIMENTS FROM Two Ports In LEBANON: BEIRUT ARMY Naval Port AND Tripoli Fishing Port
}

\author{
Carine Abi-Ghanem ${ }^{1,2}$, Celine Mahfouz ${ }^{2}$, Gaby Khalaf ${ }^{2}$, Elie Najjar ${ }^{2}$, Henri El-Zakhem ${ }^{3}$ \\ and Rima Manneh ${ }^{3}$ \\ ${ }^{1}$ Lebanese University, Faculty of Sciences 3, Tripoli, Lebanon \\ ${ }^{2}$ CNRS, National Centre for Marine Sciences, P.O. Box 534, Batroun, Lebanon \\ ${ }^{3}$ Chemical Engineering Department, University of Balamand, Balamand, Lebanon \\ abighanem@cnrs.edu.lb
}

(Received 29 October 2015 - Accepted 5 April 2016)

\section{ABSTRACT}

Abi-Ghanem Carine, Celine Mahfouz, Gaby Khalaf, Elie Najjar, Henri El-Zakhem and Rima Manneh. 2016. $\mathrm{Pb}, \mathrm{Cd}$ and $\mathrm{Cu}$ distribution and mobility in marine sediments from two ports in Lebanon: Beirut army naval port and Tripoli fishing port. Lebanese Science Journal, 17(1): 57-73.

Lead, cadmium and copper distribution and mobility in superficial sediments collected from the Beirut army navel port and Tripoli fishing port in Lebanon were studied.

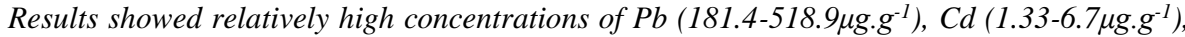
and $\mathrm{Cu}\left(141-246.8 \mu \mathrm{g} \cdot \mathrm{g}^{-1}\right)$ in sediments inside the port of Beirut. In Tripoli fishing port, $\mathrm{Pb}$ and $\mathrm{Cd}$ concentrations in sampled sediments were lower. However, higher $\mathrm{Cu}$ concentrations (up to $524.5 \mu \mathrm{g} . \mathrm{g}^{-1}$ ) were detected in Tripoli sediments. The extractability of $\mathrm{Cd}, \mathrm{Pb}$ and $\mathrm{Cu}$ from the sediments of Beirut and Tripoli port were studied by applying EDTA 0.05M and $\mathrm{CaCl}_{2}$ 0.01M extractions for two extraction times: $1 \mathrm{~h}$ and $24 \mathrm{~h}$. These extractions showed that $\mathrm{Cd}$ and $\mathrm{Pb}$ were highly mobilized by EDTA. However, only $\mathrm{Pb}$ was mobilized by $\mathrm{CaCl}_{2}$ from sediments collected in Beirut military port.

Keywords: $\mathrm{Pb}, \mathrm{Cd}, \mathrm{Cu}$, sediments, contamination, port, Lebanon

\section{INTRODUCTION}

The contamination of marine water and sediments with trace metals is a worldwide problem with serious implications for human health. Due to many natural sources (soil parent material, windblown dusts, volcanic eruptions, marine aerosols, forest fires) and anthropogenic sources (fertilizers, sewage sludges, pesticides, emissions from power stations, mining and smelting, transportation, urban/industrial complexes) trace metal levels have significantly increased in the environment (Callender, 2003). In particular, anthropogenic activities have led to an increase in trace metal levels in the air and in the water column in many heavily urbanized and industrialized zones in the world. Once in the marine water

http://dx.doi.org/10.22453/LSJ-017.1.057073

National Council for Scientific Research - Lebanon 2016@ 
column, trace metals tend to be accumulated in marine sediments (Li et al., 2001; Yuan et al., 2004). Although trace metals are not permanently trapped in sediments, they can be mobilized by the action of marine currents and turbulence of the waters (resuspension), benthic organisms (bioturbation) and diagenetic reactions that occur naturally in the sediments (Luoma, 1983; Burdige, 2006). Upon resuspension, the geochemical composition of the sediment and the chemical characteristics of the studied trace metals play a major role in its mobilization to the water column (Cantwell et al., 2002). In particularly, for $\mathrm{Cd}, \mathrm{Cu}$ and $\mathrm{Pb}$, the leaching pattern increase at low and high $\mathrm{pH}$ and a readsorption process often occurs at neutral $\mathrm{pH}$ in suboxic sediments (Hieu Ho et al., 2012). On the other hand, diagenetic reactions that occur at different levels of the sediments, are essential to the release of these metals from the sediment to the upper water column. The remobilization of $\mathrm{Fe}$ and $\mathrm{Mn}$ oxyhydroxides is the main diagenetic reaction controlling trace metal fluxes to the upper waters in oxic conditions. However, under anoxic conditions trace metals immobilization with sulfides is also very relevant especially at the interface where only $\mathrm{MnO}_{2}, \mathrm{Fe}(\mathrm{OH})_{3}$ and $\mathrm{SO}_{4}{ }^{2-}$ reduction takes place (Riguaud et al., 2013).

These contaminants can also be ingested and absorbed through dermal contact, which pose threats to many benthic organisms. These phenomena promote the bioavailability and bioaccumulation of trace metals to higher levels in the food chain (Mulligan et al., 2001).

In Lebanon, many studies were conducted along the coastal zone to evaluate trace metals contamination in the water column, in superficial sediments and in bioindicators Brachidontes variabilis (Nakhlé, 2003; Fakhri, 2005; Abi-Ghanem et al., 2009a; 2009b; 2010; 2012). These studies highlighted the presence of several hot spots (Dora, Antelias, Selaata, etc...), where trace metal levels reached concentrations comparable to marine sediments in highly polluted areas in the world, where $\mathrm{Pb}$ reached $100 \mu \mathrm{g} \mathrm{g}^{-1}$ and $\mathrm{Cd}$ reached a concentration of $3 \mu \mathrm{g} \mathrm{g}^{-1}$ (Abi-Ghanem et al., 2009b).

Although trace metal distribution at several hot spots along the Lebanese coast has been assessed, less is known about their distribution in the Lebanese ports. These areas, as in many parts of the world, are susceptible to receiving significant metal inputs from different anthropogenic activities (boat maintenance, paint particles derived from boat cleaning or from grounded and abandoned vessels, shipping activities, sacrificial anodes, leaching of urban surfaces as roads and nearby parkings, untreated wastewater discharges, etc...). On the other hand, they are designed to minimize hydrodynamic energy, thus enhancing the accumulation of finer sediments where trace metals tend to accumulate (Huerta-Diaz et al., 2008). The only trace metal study conducted on three sediment cores sampled in a yacht port in Lebanon (Jounieh) have shown that $\mathrm{Pb}$ and $\mathrm{Cd}$ levels are several orders of magnitude higher than the natural levels, indicating that the sediments in the port are moderately to strongly polluted (Tahchy, 2011)

The objectives of the present study were to determine trace metals $(\mathrm{Pb}, \mathrm{Cd}$ and $\mathrm{Cu})$ distribution and mobility in marine sediments from two ports in Lebanon. $\mathrm{Pb}$ and $\mathrm{Cd}$ are chosen because of their high toxicity to biota and their ability to disturb the metabolic processes even at very low concentrations (Picot, 2003) and also because of the fact that they are part of the priority polluting substances list elaborated in the framework of the water Directive of the European Union, to which Lebanon is also associated. On the other hand, this study also focuses on $\mathrm{Cu}$ concentrations that are often reported at high levels in port regions and are often related to antifouling paints (Singh \& Turner, 2009). 
The studied ports are located in the most populated cities along the Lebanese coast. Moreover, they encompass two different activities: the Beirut military port covers military activities and the Tripoli port is well known for its fishing activities. Since the quantification of total metal concentrations in sediment does not give a clear idea on their mobility and on their potential ecological risk, a particular attention was also given to the evaluation of their mobility in the studied sediments by applying single extraction procedures using two types of extractants: ethylene diaminetetraacetic acid (EDTA) $0.05 \mathrm{M}$ and calcium chloride $\left(\mathrm{CaCl}_{2}\right)$ $0.01 \mathrm{M} . \mathrm{CaCl}_{2}$ is frequently claimed to measure bioavailable metals since it works by exchanging $\mathrm{Ca}$ with metals on the exchange complex (Houba et al., 1997). On the other hand, EDTA is a synthetic chelating agent that forms strong complexes with metals associated with the sediment components throughout various ways: ion exchange, adsorbtion, organically bound, or occlusion into inorganic compounds as iron $(\mathrm{Fe})$ and manganese $(\mathrm{Mn})$ oxides and clay minerals (Paya-Perez et al., 1993). It is thus recently used to study trace metals mobility in soils and sediments (Bermond et al., 2005; Fangueiro et al., 2005; Manouchehri, 2006).

\section{MATERIALS AND METHODS}

\section{Study area}

\section{Tripoli fishing port}

The city of Tripoli, $85 \mathrm{~km}$ north of Beirut, is a transit area between Beirut and Syria. It represents today with its international transit port the commercial and industrial center of Northern Lebanon and the second city in Lebanon after Beirut in term of density of the population and anthropogenic activities. Its port $\left(34^{\circ} 27^{\prime} \mathrm{N}, 35^{\circ} 49^{\prime} \mathrm{E}\right)$, in the region of $\mathrm{Al}-$ Mina town, serves as a relay for trade between the Eastern Mediterranean and the West as well as a transit point for caravans towards Northern Syria. The port currently receives about 450 ships each year with an average of 37 ships each month. It is divided into two major parts: the fishermen and the industrial port. This study will focus on the first port reserved for small fishing vessels. In March 2013, a sediment sampling campaign was carried out in the port of Tripoli. Eleven points (S2 to S12) covering the entire surface of the port with a depth of 2 to $5 \mathrm{~m}$ were sampled (Fig. 1a). Sediments were collected with a grab sampler and placed into polyethylene bags for further analysis. The $\mathrm{pH}$ and $\mathrm{Eh}$ were determined directly on board using a multiparameter analyzer.

\section{Beirut military port}

The military port of Beirut $\left(33^{\circ} 54^{`} \mathrm{~N}, 35^{\circ} 30^{`} \mathrm{E}\right)$, or Beirut Naval Base, is the first naval base in Lebanon and the headquarters of the Lebanese Navy. Established in 1950, the base comprises a part of Beirut port which suffers from the anthropogenic impact of sewage, solid wastes and port activities. In April 2012, a sediment sampling campaign was conducted in the military port in Beirut with the scientific vessel "CANA" (CNRS). Twelve sediment sampling points were chosen in order to cover the surface of the port from B1 to B12 (Fig. 1b). The inner sampling points B1 to B9 covered depth ranging from 5 to $10 \mathrm{~m}$; while B10 to B12 sampling points were deeper reaching $60 \mathrm{~m}$. At each sampling point, 1 to $2 \mathrm{~kg}$ of sediments were collected with a grab sampler. The $\mathrm{pH}$ and Eh were determined directly on board using a multiparameter analyzer. As for Eh measures, the reference electrode used on samples is the Normal Hydrogen Electrode. The samples were then placed in polyethylene bags. The sediments inside the port were black with an unpleasant odor. 

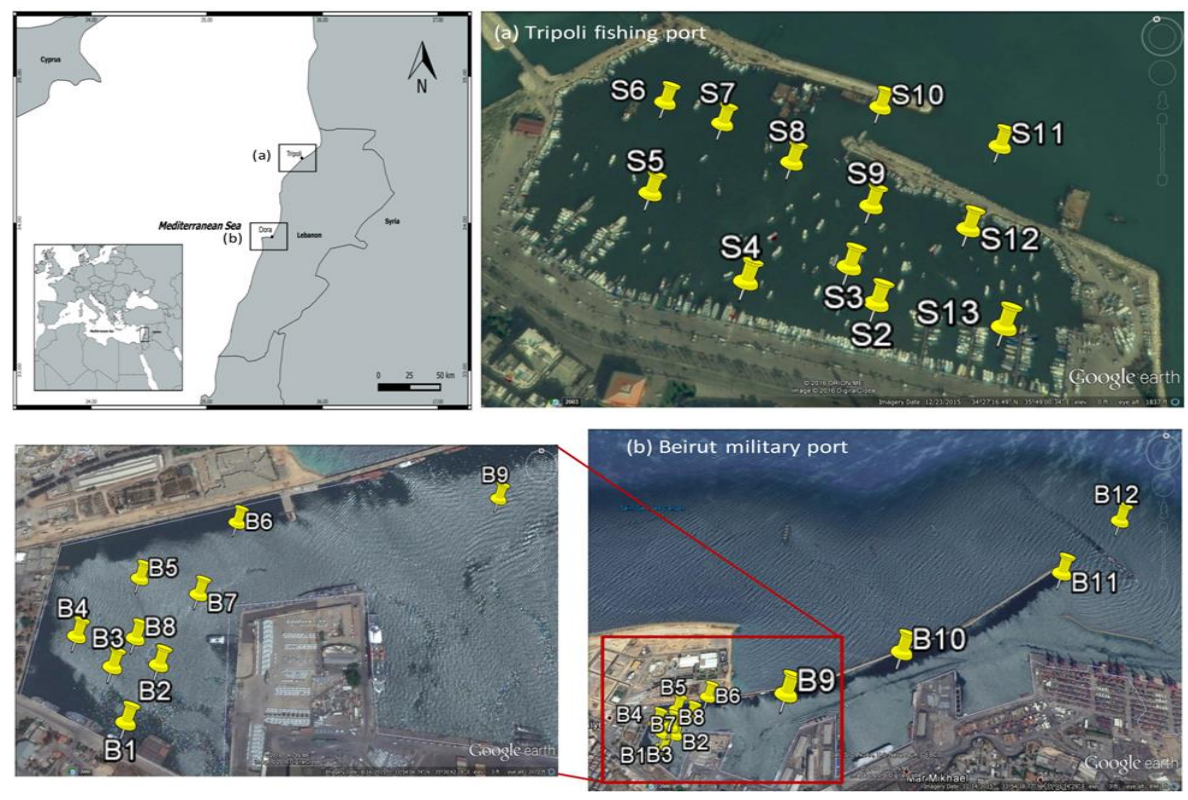

Figure 1. Sampling point locations in two ports on the Lebanese coast: Tripoli fishing port (a) and Beirut military port (b).

\section{Laboratory analysis}

\section{Sediment samples}

Collected marine sediments were freeze-dried, then dry sieved through a $63 \mu \mathrm{m}$ sieve. $200 \mathrm{mg}$ of dry sediment $(<63 \mu \mathrm{m})$ were digested for $2 \mathrm{~h} 30 \mathrm{~min}$ at $120^{\circ} \mathrm{C}$ with $250 \mu \mathrm{l}$ $\mathrm{HNO}_{3}(65 \%$, Suprapur, Merck), $750 \mu \mathrm{HCl}$ (30\%, Suprapur, Merck) and $6 \mathrm{ml} \mathrm{HF} \mathrm{(48 \% ,}$ Suprapur, Merck) in Teflon bombs according to the protocol described by Loring and Rantala (1990). Trace metal concentrations were determined by atomic absorption spectrometry GFAAS (Hitachi Z-5000).

The wavelengths used for $\mathrm{Pb}, \mathrm{Cd}$ and $\mathrm{Cu}$ quantification were 283.3, 228.8 and $324.75 \mathrm{~nm}$, respectively. Limits of detection were 0.02 and $0.2 \mu \mathrm{g} \mathrm{g} \mathrm{g}^{-1}$ for $\mathrm{Cd}$ and $\mathrm{Pb}$, respectively. Yields between $3 \%$ and $5 \%$ proved the reproducibility of the limits. The accuracy of the methods was assessed by the analysis of certified reference material (CRM), in particular the NRC-MESS 2 and IAEA 405. The analytical results obtained were within the certified analytical limits.

\section{Extraction tests}

To determine the mobility of $\mathrm{Pb}, \mathrm{Cd}$ and $\mathrm{Cu}$, two extractants were applied: ethylene diaminetetraacetic acid (EDTA) and calcium chloride $\mathrm{CaCl}_{2}$. Three sediments sampling sites were selected in Beirut military port B1, B5 and B12. B1 and B5 were chosen for being very close to the sources of contamination inside the port and B12 since it represents a sampling 
point external to the port. Also, the mobility of these metals in Tripoli fishing port was studied at the two sampling points S2 and S13, which are located the closest to the inner parts of the port. The extraction tests were conducted on the fraction $<63 \mu \mathrm{m}$ of the sediments. $25 \mathrm{ml}$ of extractant were added to $0.5 \mathrm{~g}$ of sediments and rotated end-over-end at $26 \mathrm{rpm}$ for two reaction times: $1 \mathrm{~h}$ and $24 \mathrm{~h}$. Only for Tripoli port and with $\mathrm{CaCl}_{2} 0.01 \mathrm{M}$, the two extraction times that were adopted were $1 \mathrm{~h}$ and $2 \mathrm{~h}$, in order to avoid trace metals readsorption on the solid phase of the sediments (unpublished data). The supernatants were then separated by filtration using a $0.45 \mu \mathrm{m}$ Millipore filter, and then stored in vials at $4^{\circ} \mathrm{C}$ until analysis by atomic absorption spectrometry GFAAS (Hitachi Z-5000).

\section{Geoaccumulation index (I-geo)}

To estimate the anthropogenic impact on sediments and in order to quantify and evaluate their trace metals enrichment, the technique of Muller (1979) was used. This technique is based on the calculation of the index of geoaccumulation (Igeo) that allows classifying sediments according to their degree of trace metals enrichment. The index is calculated as follows:

$$
I_{\text {geo }}=\log _{2}\left(\frac{C_{n}}{1.5 B_{n}}\right)
$$

$\boldsymbol{C}_{\boldsymbol{n}}$ : measured concentration of the studied metal $\mathrm{n}(\mathrm{n}=\mathrm{Pb}, \mathrm{Cd}$ or $\mathrm{Cu})$

$\boldsymbol{B}_{n}$ : background concentration corresponding to the detected metal levels in deep sedimentary layers of Akkar which is a site located at the north of Lebanon and where deep sea sediments layers are free from any anthropogenic impact $\left(6.21 \mu \mathrm{g} \cdot \mathrm{g}^{-1}\right.$ for $\mathrm{Pb}, 0.19 \mu \mathrm{g} \cdot \mathrm{g}^{-1}$ for $\mathrm{Cd}$, $11 \mu \mathrm{g} . \mathrm{g}^{-1}$ for $\mathrm{Cu}$ ) (Abi-Ghanem et al., 2009a). The choice of the background concentration appears to be reasonable by comparing the $\boldsymbol{B}_{\boldsymbol{n}}$ values with the "average shale" (Turekian \& Wedepohl, 1961).

1.5: factor used to offset the possible variations of background concentrations due to the lithogenic effect.

\section{Data treatment}

Data analysis was performed using "XLSTAT - Pro" 2013 (Addinsoft). Half the limit of quantification was assigned for statistical analysis, when values were below the limit of quantification. Correlations between metals in sediments at the two ports were tested using the Spearman coefficient. Percentages of extracted metals at different extraction times were tested using a Mann-Whitney $U$ test or student's $t$-test when the necessary assumptions of normality and the homogeneity of variances for parametric statistics were satisfied. The level of significance was set at $\alpha=0.05$.

\section{RESULTS AND DISCUSSION}

\section{pH and Eh (reduction potential) levels}

In Beirut military port, $\mathrm{pH}$ values fluctuated between 7.2 and 7.9. For the sediments inside the port in the locations $\mathrm{B} 1$ to $\mathrm{B} 8, \mathrm{pH}$ values ranged from 7.2 to 7.9 and stabilized at the points $\mathrm{B} 9$ to $\mathrm{B} 12$ at narrower $\mathrm{pH}$ of 7.6 , which is comparable to $\mathrm{pH}$ detected in superficial coastal sediments in Lebanon (Fakhri, 2005). $\mathrm{pH}$ values of the sediments of Tripoli port varied between 7.1 and 7.9. These values are comparable to $\mathrm{pH}$ detected in superficial sediments of other ports contaminated with urban waste waters (Ben Allal et al., 2011). 
Samples S2, S3, S4, S5, S8, S9, S12 and S13 in the inner parts of the port were characterized by $\mathrm{pH}$ ranging from 7.1 to 7.7 . These $\mathrm{pH}$ values are comparable to those obtained in sediments collected in the port of Beirut. However, higher $\mathrm{pH}$ values $(7.7$ - 7.8) were detected in S6, S10 and S11.

As for the oxidation reduction potential (Eh), the sampling points closest to the inner side of Beirut port B1, B2, B3 and B4 represented negative reduction potentials -132 , $-206,-168.8$ and $-160 \mathrm{mV}$, respectively. These values showed total anoxia at these points, which is also strengthened by the strong smell of hydrogen sulfide in these sediments. These results can be related to the release of sewage effluent in the harbor which tends to cover the bottom by a thick layer of sludge. Starting at the point B5, reduction potential of sediments became positive. Indeed, the values of Eh increased from B5 $(23.5 \mathrm{mV})$ to B7 $(92.3 \mathrm{mV})$, decreased at $\mathrm{B} 8(\mathrm{Eh}=23.5 \mathrm{mV})$ and stabilized at $\mathrm{B} 9, \mathrm{~B} 10, \mathrm{~B} 11$ and $\mathrm{B} 12$ points around 100 $\mathrm{mV}$. These positive values of reduction potential indicated the presence of oxic conditions related to the mixing of sediments by marine currents.

On the other hand, all reduction potential values obtained for Tripoli harbour sediments varied between $-415 \mathrm{mV}$ and $-112 \mathrm{mV}$, an indication that Tripoli port sediments are totally anoxic. S2, S12 and S13 sites had the lowest values of $-415 \mathrm{mV}$, - 340mV and $380 \mathrm{mV}$, respectively. These sampling points located on the same side of the port reflected very clearly the impact of wastewater discharges inside the port. Moreover, the sampled sediments in Tripoli port were characterized by a very strong smell of hydrogen sulfide.

\section{$\mathrm{Pb}, \mathrm{Cd}$ and $\mathrm{Cu}$ distribution}

\section{Beirut military port}

The nearest sampling points to the internal edge of the port (B1 to B8) represented high $\mathrm{Pb}$ concentrations ranging from 181.4 to $518 \mu \mathrm{g} . \mathrm{g}^{-1}$. These concentrations are comparable to the upper limits detected in sediments of other Mediterranean harbors under the impact of the discharge of untreated wastewater, the presence of solid waste, and harbors activities (boat maintenance, paint particles derived from boat cleaning or from grounded and abandoned vessels, shipping activities, sacrificial anodes, leaching of urban surfaces as roads and nearby parkings, untreated wastewater discharges, etc...) (Adamo et al., 2005; Tessier et al., 2011). These $\mathrm{Pb}$ concentrations obtained in Beirut military port sediments are higher than those found in the superficial sediments of ATCL-Yacht port (Jounieh-Lebanon) (17.41 and $45.7 \mu \mathrm{g} . \mathrm{g}^{-1}$ ) (Tahchy, 2011; unpublished data). Lead concentrations decreased at points B9 to $\mathrm{B} 12$, and reached the lowest value at B11 $\left(19.2 \mu \mathrm{g} . \mathrm{g}^{-1}\right)$ (Table 1). This latter Pb concentration is comparable to values found in superficial sediments in Akkar $\left(15.7 \mu \mathrm{g} . \mathrm{g}^{-1}\right)$, where $\mathrm{Pb}$ detected originated from gasoline combustion (Abi-Ghanem et al., 2009a).

Cadmium levels in sediments of Beirut military port ranged from $0.26 \mu \mathrm{g} \cdot \mathrm{g}^{-1}$ to $6.7 \mu \mathrm{g} . \mathrm{g}^{-1}$. High $\mathrm{Cd}$ levels detected inside the port can originate from the harbor activities discussed above as well as from waste water discharged into the harbor. Cd levels detected in points B6, B8 and B7 (Table 1) are many orders of magnitude higher than levels detected in other Mediterranean ports undergoing the impact of anthropogenic sources such as discharges of waste water and solid waste (Dalman et al., 2006), and also higher than levels detected in highly contaminated area in Lebanon (Selaata) (Abi-Ghanem, 2008). Cadmium concentrations, similar to lead concentrations, also decreased at points B9 to B12. However, 
such $\mathrm{Cd}$ concentrations that remained high compared to $\mathrm{Cd}$ levels detected in the sediments of ATCL port $\left(0.17\right.$ and $\left.0.28 \mu \mathrm{g} . \mathrm{g}^{-1}\right)$ (Tahchy, 2011), are probably related to the continuous export of contaminated particles from the inner parts of the port to the external parts, likely induced by sediment resuspension during boats traffic (Tessier et al., 2011).

$\mathrm{Cu}$ concentrations in the studied sediments ranged from 27.5 to $246.8 \mu \mathrm{g} \cdot \mathrm{g}^{-1}$ (Table 1). Internal high $\mathrm{Cu}$ concentrations are comparable to those detected in other Mediterranean harbor sediments with similar industrial activities (Romano et al., 2004; Adamo et al., 2005). In the external parts of the port, copper concentrations decreased and reached the lowest value in the sediments at $\mathrm{S} 11\left(27.5 \mu \mathrm{g} . \mathrm{g}^{-1}\right)$. This value remains very high compared to values obtained in Akkar deep sediment layers considered safe from contamination (11 $\left.\mu \mathrm{g} . \mathrm{g}^{-1}\right)$ (AbiGhanem, 2008). This copper contamination could largely come from antifouling used in paints, especially that analysis of antifouling paint residues indicated that concentrations of $\mathrm{Cu}$ concentration reached $300 \mathrm{mg} \mathrm{g}^{-1}$ (Singh \& Turner, 2009).

\section{Tripoli fishing port}

Lead levels in marine sediments of the port of Tripoli fluctuated between $40.2 \mu \mathrm{g} . \mathrm{g}^{-1}$ and $92.8 \mu \mathrm{g} . \mathrm{g}^{-1}$ (Table 1). These concentrations are comparable to concentrations detected in Taranto Gulf (Southern Italy) (Buccolieri et al., 2006), but lower than those detected in Beirut military port and in other Mediterranean harbor sediments (Huntingford \&Turner, 2011). Pb concentrations decreased gradually while moving away from the inner edge of the port and the lowest value was found in S10 point $\left(40.2 \mu \mathrm{g} . \mathrm{g}^{-1}\right)$. This value is comparable to the highest levels found by Tahchy (2011) in harbor sediments collected from the Marina ATCL, Jounieh-Lebanon, where $\mathrm{Pb}$ concentrations varied between 20.5 and $45.7 \mu \mathrm{g} . \mathrm{g}^{-1}$. These relatively lower $\mathrm{Pb}$ concentrations detected in Tripoli fishing port can be related to the reduced in the shipping activities especially fuel combustion inside the port compared to Beirut naval port and also to lower impact of urban discharges.

Cd concentrations in sediments collected from Tripoli port varied between 0.24 and $0.64 \mu \mathrm{g} . \mathrm{g}^{-1}$ (Table 1). These Cd levels are comparable to the concentrations found in sediments of the port of Croisic in France (Marrec \& Proulhac, 2012) can be related to many anthropogenic activities, such as oil and coal combustion and discharges of urban effluents. $\mathrm{Cd}$ concentrations decreased while moving out gradually from the internal edge of the port to $\mathrm{S} 11$ where Cd level reached $0.24 \mu \mathrm{g} . \mathrm{g}^{-1}$. This value is comparable to those found in the sediments of the commercial port of Bastia in France (BRGM, 2001). On the other hand, when compared to $\mathrm{Cd}$ concentrations in Beirut port, the $\mathrm{Cd}$ levels in Tripoli sediments showed that the latter is less contaminated.

$\mathrm{Cu}$ concentrations in the sediments of Tripoli port ranged from 34.6 to $524.5 \mu \mathrm{g} . \mathrm{g}^{-1}$ (Table 1). S13, the nearest point to the internal borders of the port, showed the highest copper concentration $\left(524.5 \mu \mathrm{g} \cdot \mathrm{g}^{-1}\right)$. This value, which is much higher than the $\mathrm{Cu}$ levels detected in the sediments of the port of Beirut, is comparable to $\mathrm{Cu}$ concentrations detected in some harbor sediments in the world suffering from anthropogenic activities (Romano et al., 2004). However, the most important source of copper in the case of Tripoli port has to be the abandoned boat that is very close to $\mathrm{S} 13$ which is liberating high amount of particulate copper in the water (Singh \& Turner, 2009). Cu concentrations decreased while moving away from the internal edges. Detected values in this part of the port were comparable to the 
concentrations found in the sediments of Beirut military port. The lowest concentration of $\mathrm{Cu}$ $\left(55.7 \mu \mathrm{g} . \mathrm{g}^{-1}\right)$ was detected at S11 located at the entrance of the port.

\section{TABLE 1}

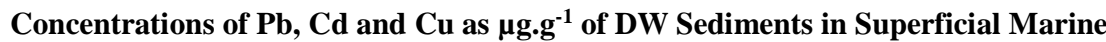
SDediments of Tripoli Fishing Port and Beirut Navy Port

\begin{tabular}{cccc}
\hline Sampling site & \multicolumn{3}{c}{$\mu \mathrm{gg}^{-1} \mathrm{DW}$} \\
\hline Tripoli fishing port & $\mathrm{Pb}$ & $\mathrm{Cd}$ & $\mathrm{Cu}$ \\
\hline S2 & 91.9 & 0.415 & 196.6 \\
S3 & 63.1 & 0.336 & 131.1 \\
S4 & 61.9 & 0.341 & 140.5 \\
S5 & 55 & 0.244 & 134.5 \\
S6 & 45.9 & 0.238 & 133.1 \\
S7 & 43 & 0.237 & 83.9 \\
S8 & 45.1 & 0.275 & 98.3 \\
S9 & 62 & 0.311 & 108 \\
S10 & 40.2 & 0.245 & 63.1 \\
S11 & 46.8 & 0.287 & 55.7 \\
S12 & 73.7 & 0.363 & 161.8 \\
S13 & 92.8 & 0.644 & 524.5 \\
\hline Beirut Navy port & & & \\
\hline B1 & 414.5 & 2.27 & 246.8 \\
B2 & 296.9 & 1.56 & 207.4 \\
B3 & 366.6 & 2.42 & 171.2 \\
B4 & 181.4 & 1.33 & 152 \\
B5 & 328.3 & 2.95 & 176.8 \\
B6 & 274.4 & 4.45 & 158.3 \\
B7 & 246.8 & 6.7 & 141 \\
B8 & 518.9 & 3.44 & 203.7 \\
B9 & 128.3 & 0.74 & 130.6 \\
B10 & 70.2 & 0.56 & 72.8 \\
B11 & 19.2 & 0.31 & 27.5 \\
B12 & 36.8 & 0.26 & 35.6 \\
\hline & & & \\
\hline
\end{tabular}


Moreover a good positive correlation was found between the studied trace metals at each of the two sampling sites (Table 2) which highlighted the multicontamination of the sediments in the two ports.

\section{Geoaccumulation index (I-geo)}

According to Igeo values and to Muller's classification (Table 3), B1 to B8 sediment samples in Beirut military port were classified as strongly to extremely polluted regarding $\mathrm{Pb}$, and moderately to strongly polluted regarding $\mathrm{Cd}$. However, sediments at $\mathrm{B} 9$ to B12 sampling points in the same port were considered moderately to strongly polluted sediments regarding $\mathrm{Pb}$ and unpolluted to moderately polluted regarding $\mathrm{Cd}$. This classification in Beirut military port sediments showed the extremely negative impact of the different sources of contamination in the port: urban wastewaters discharges, solid wastes, and harbor activities.

\section{TABLE 2}

\section{Spearman Rank Correlation Matrix between Trace Elements in Sediments from Tripoli Fishing Port and Beirut Navy Port}

\begin{tabular}{lrrr}
\hline & $\mathrm{Pb}$ & $\mathrm{Cd}$ & $\mathrm{Cu}$ \\
\hline Tripoli fishing port & & & \\
$\mathrm{Pb}$ & 1 & & \\
$\mathrm{Cd}$ & $0.872 * * *$ & 1 & \\
$\mathrm{Cu}$ & $0.769^{* *}$ & $0.936^{*}$ & 1 \\
Beirut navy port & & & \\
$\mathrm{Pb}$ & 1 & & \\
$\mathrm{Cd}$ & $0.550^{*}$ & 1 & \\
$\mathrm{Cu}$ & $0.902 * * *$ & $0.452^{*}$ & \\
\hline$* \mathrm{p}<0.05$ & & & \\
$* * \mathrm{p}<0.005$ & & & \\
$* * * \mathrm{p}<0.0005$ & & &
\end{tabular}

This highlights the need for a further study of the mobility on these trace metals and their potential risk. The negative value of Igeo obtained for Cd at B12 (I geo $=-0.132<0)$ shows that these sediments can be classified as non-polluted and indicates that $\mathrm{Cd}$ sources of contamination in the port fail to contaminate sediments more offshore. On the other hand, copper geoaccumulation index showed that the sediments in Beirut port B1 to B8 are strongly polluted. Even at B9, B10 and B12 sites, the sediments are moderately to strongly polluted. This copper pollution can be related to the hulls of the boats where $\mathrm{Cu}$ seems increasingly used as anti-fouling for its toxicity on phytoplankton and other organisms (Bisson et al., 2005), and may also be attributed to metallic solid waste dispersed in the bottom of the port. 
In Tripoli fishing port, lead geoaccumulation index values ranged between 2 and 4 , indicating that these sediments belong to classes 3 and 4 (Table 3) and are considered moderately to strongly polluted with $\mathrm{Pb}$. The samples at sites $\mathrm{S} 2$ and $\mathrm{S} 13$, closest to the internal diameter of the port, belong to class 4 and they are considered strongly polluted (Table 3). This is primarily due to the impact of wastewater effluents that are released in the port without any treatment and also to fuel discharges coming from fishing vessels that are parked in this area. Geochemical indexes for cadmium showed that the quality of the studied sediments in Tripoli fishing port varied between unpolluted to moderately polluted. S13 site sample was the only one that belongs to class 2 and thus considered moderately polluted with $\mathrm{Cd}$. However, values of copper geoaccumulation indexes showed that sediments at S13, the nearest point to the internal boundaries of the port, were strongly to very strongly polluted (Table 3). Sediments in the other sampling sites were classified strongly polluted or moderately to strongly polluted. This strong $\mathrm{Cu}$ contamination, even at the furthest points to the edges of the port, was related to sewage discharges and to copper oxides used as antifouling on the boats (Chiffoleau, 2001).

TABLE 3

Muller's Classification for the Geoaccumulation Index (Muller, 1979)

\begin{tabular}{|c|c|c|}
\hline $\begin{array}{l}\text { Igeo } \\
\text { value }\end{array}$ & Class & Quality of sediment \\
\hline$\leq 0$ & 0 & Unpolluted \\
\hline $0-1$ & 1 & $\begin{array}{l}\text { From unpolluted to } \\
\text { moderately polluted }\end{array}$ \\
\hline $1-2$ & 2 & Moderately polluted \\
\hline $2-3$ & 3 & $\begin{array}{l}\text { From moderately } \\
\text { polluted to strongly } \\
\text { polluted }\end{array}$ \\
\hline $3-4$ & 4 & Strongly polluted \\
\hline $4-5$ & 5 & $\begin{array}{l}\text { From strongly } \\
\text { extremely polluted }\end{array}$ \\
\hline$>5$ & 6 & Extremely polluted \\
\hline
\end{tabular}

\section{$\mathrm{Pb}, \mathrm{Cd}$ and $\mathrm{Cu}$ extraction by EDTA}

\section{Beirut military port}

By comparing the levels of extracted $\mathrm{Cd}, \mathrm{Pb}$ and $\mathrm{Cu}$ obtained from the two extraction times (Fig. 2), it can be stated that they were significantly higher for the three metals at $24 \mathrm{~h}$ extraction time ( $<<0.05)$, suggesting that the extraction time of one hour was not sufficient to reach the highest extraction rate of the three metals by EDTA. Moreover, the highest rates of $\mathrm{Cd}$ extraction was at B1 and B5 (82-97\%) (Fig. 2). On the other hand, Pb extraction level was lower and varied between $50 \%$ and $60 \%$. These results can be explained by the fact that cadmium is mostly organically bound, exchangeable and water soluble, whereas, lead is slightly mobile and bound to the residual fraction (Kabata-Pendias \& Pendias, 1992). The lowest extraction rates were those of $\mathrm{Cu}$, ranging between $17 \%$ and $37 \%$. 
In the case of $\mathrm{Cd}$ at $\mathrm{B} 12$, the extracted rate was much lower (48-50\%) compared to those at B1 and B5. Subsequently, it can be concluded that Cd at B1 and B5, which are moderately to heavily polluted, were much more mobile compared to $\mathrm{Cd}$ at $\mathrm{B} 12$ (which is not polluted). The Cd extraction rates at B1 and B5 were also high compared to those obtained by Abi-Ghanem et al. (2009b) who applied the same method at many sites along the Lebanese coast. This suggests that $\mathrm{Cd}$ inside Dora port represents higher environmental risk.

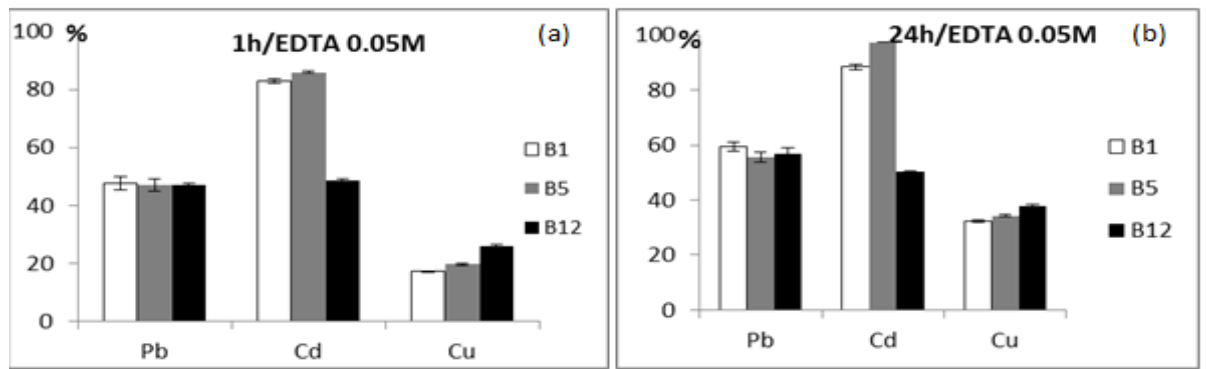

Figure 2. Levels (\%) of extracted $\mathrm{Pb}, \mathrm{Cd}$ and $\mathrm{Cu}$ by EDTA $0.05 \mathrm{M}$ after $1 \mathrm{~h}$ (a) and $24 \mathrm{~h}$ (b) extraction times from Beirut military port sediments.

For $\mathrm{Pb}$, the extracted rates were similar (46-59\%) at the three studied sampling points B1, B5 and B12. However, these values are low compared to the $72-93 \%$ rates obtained by Abi-Ghanem et al. (2009b) at a nearby sampling point. Subsequently, it can be concluded that $\mathrm{Pb}$ in our case was more tightly bound to the sediments. The relatively high affinity of $\mathrm{Pb}$ to the sediments inside the port can be explained by its possible integration into the silicate fraction of sediment which reduces its mobilization by EDTA (Fuller \& Davis, 1987).

\section{Tripoli fishing port}

The level of extracted Cd was the highest at S2 and S13 and varied between 96 and $77 \%$ (Fig. 3), and the level of extracted lead was lower (35\%-60\%), and that of copper was the lowest $(12-46 \%)$. However, only the $\mathrm{Cu}$ extracted level at S13 and S2 after $24 \mathrm{~h}$ of agitation time was significantly higher $(\mathrm{p}<0.005)$ than those extracted at the same sites after $1 \mathrm{~h}$ of extraction time. This shows that $\mathrm{Cd}$ and $\mathrm{Pb}$ in Tripoli fishing port are rapidly mobilized within the first hour of extraction time.

Similar to Beirut military port, the high level of extracted Cd (77-95\%) indicate that the $\mathrm{Cd}$ is highly mobile and represents the highest environmental risk. If these levels were compared to those obtained by Abi-Ghanem et al. (2009b) who applied the same method to the sediments of Selaata (62-65\%), Dora (45-50\%) and Akkar (60\%), we find that the Cd extracted level from the port of Tripoli was much higher. On the other hand, the extracted lead level in this study was lower than that of cadmium, and was much lower than those extracted from other coastal sediments (Abi-Ghanem et al., 2009b), suggesting that $\mathrm{Pb}$ is less mobile than $\mathrm{Cd}$ and subsequently, it is more strongly bound to the solid phase of the sediment (Nowak et al., 2001).

In addition, extracted copper level indicated that copper was the least mobile element in the presence of EDTA. It is therefore the most difficult to extract, especially during 
the first hours of agitation time. When these values were compared with those obtained by Leleyter et al. (2012) who applied the same method to the estuarine and marine sediments collected from many areas in France, it is evident that the extracted copper level from S13 after $1 \mathrm{~h}$ of agitation time was comparable.

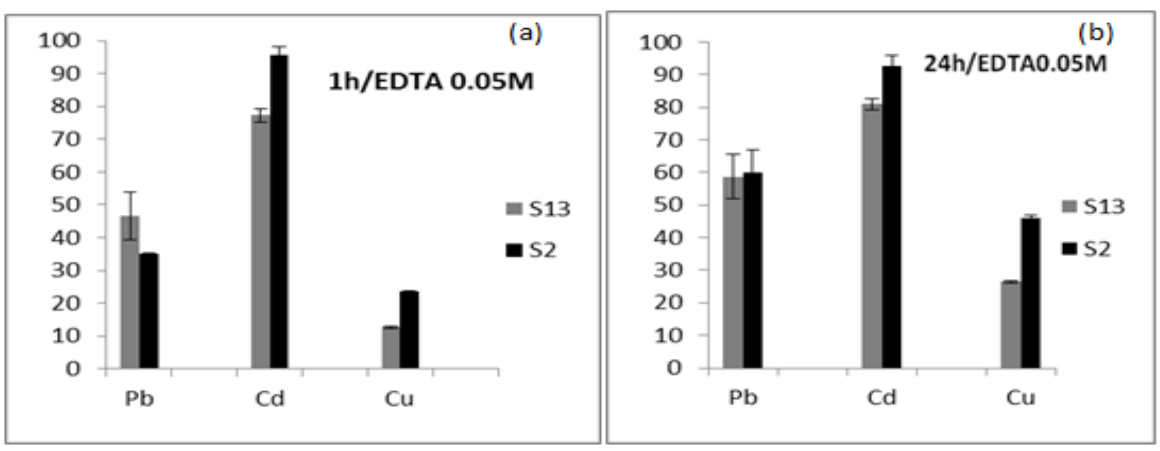

Figure 3. Percentages of extracted $\mathrm{Pb}, \mathrm{Cd}$ and $\mathrm{Cu}$ by EDTA $0.05 \mathrm{M}$ after $1 \mathrm{~h}$ (a) and $24 \mathrm{~h}$ (b) extraction times from Tripoli fishing port sediments.

\section{$\mathrm{Pb}, \mathrm{Cd}$ and $\mathrm{Cu}$ extraction by $\mathrm{CaCl}_{2}$}

\section{Beirut military port}

Results presented in Figure 4 show that among the three studied metals, $\mathrm{Pb}$ is more easily mobilized and subsequently presents more environmental risk (Sahuquillo et al., 2003). In fact, very low percentages of $\mathrm{Cd}(1-2.5 \%)$ and $\mathrm{Cu}(0.1-0.3 \%)$ are extracted by $\mathrm{CaCl}_{2} 0.01 \mathrm{M}$ after $1 \mathrm{~h}$ and even $24 \mathrm{~h}$ hours of extraction time. On the other hand higher $\mathrm{Pb}$ extracted concentrations $(8-31 \%)$ were obtained after $1 \mathrm{~h}$ of extraction time compared to $\mathrm{Pb}$ percentages obtained after $24 \mathrm{~h}$ of agitation which suggests the occurrence of readsorption and/or precipitation of the extracted $\mathrm{Pb}$ on the solid phase of the sediment (Bermond \& Malenfant, 1990).

It is to be noted that Cd extracted concentrations in B1 (2.32\%), B5 (3.83\%) and B12 $(1.59 \%)$ after an hour of extraction time, are comparable to those obtained by Hamdoun et al. (2010) and Sahuquillo et al. (2003). In addition, percentages of $\mathrm{Pb}$ extracted from B5 $(15.84 \%)$ and B12 (31.25\%) (Fig. 4) are very high compared to those extracted from dredged sediments along the English-French littoral (Hamdoun et al., 2010) which shows that $\mathrm{Pb}$ in our case is more mobile and subsequently represents higher risk.

On the other hand, $\mathrm{Cu}$ extracted percentages are very low with a maximum value of $0.37 \%$ at B1 after 24 hours of extraction time. This value is similar to the one obtained by Sahuquillo et al. (2003) after 1h of extraction. 


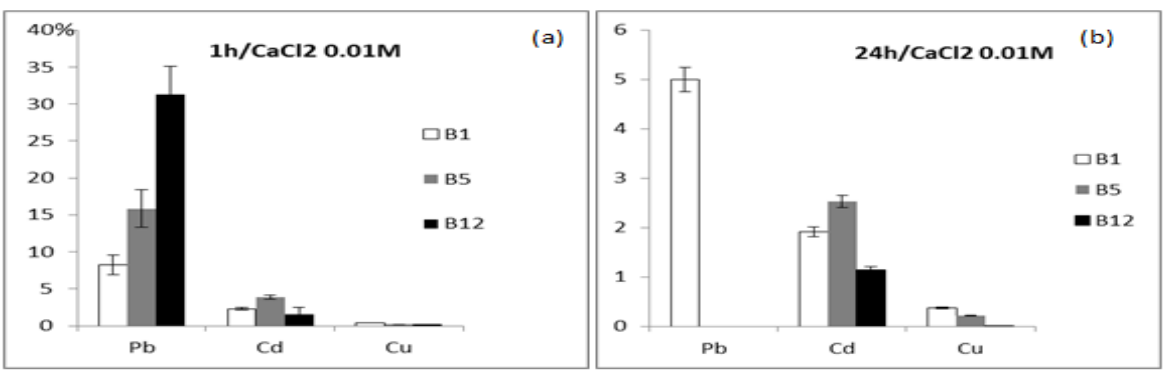

Figure 4. Levels (\%) of extracted $\mathrm{Pb}, \mathrm{Cd}$ and $\mathrm{Cu}$ by $\mathrm{CaCl}_{2} \mathrm{O.01M}$ after $1 \mathrm{~h}$ (a) and $24 \mathrm{~h}$ (b) extraction times from Beirut military port sediments.

Tripoli fishing port

Extractions by $\mathrm{CaCl}_{2} 0.01 \mathrm{M}$ were conducted during two extraction times: $1 \mathrm{~h}$ and $2 \mathrm{~h}$ (Pueyo et al., 2004; Jamali et al., 2009) (Fig.5). Longer extraction times were not adopted in order to prevent the reabsorption of the mobilized trace metals on the solid phase of the sediment which took place during a preliminary extraction test applied to the sediments of Tripoli fishing port. However, as shown in Figure 5, the only metal that was extracted within these extraction times was copper and at very low levels which varied between 0.16 and $0.18 \%$.

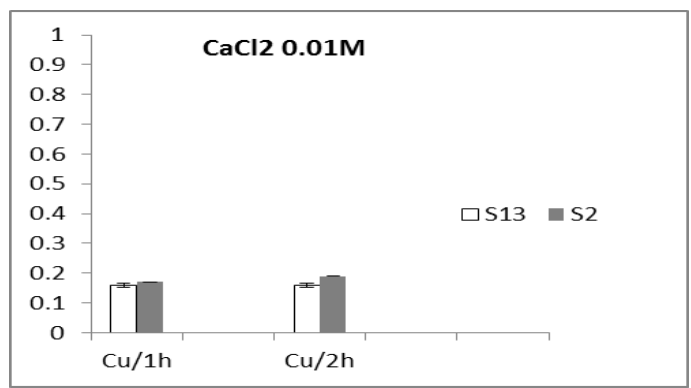

Figure 5. Levels (\%) of extracted $\mathrm{Cu}$ by $\mathrm{CaCl}_{2} \mathrm{0.01M}$ after $1 \mathrm{~h}$ and $2 \mathrm{~h}$ of extraction times from Tripoli fishing port sediments.

These low levels of $\mathrm{Cu}$ mobilized as well as the quasi-absence of $\mathrm{Pb}$ and $\mathrm{Cd}$ extracted by $\mathrm{CaCl}_{2} 0.01 \mathrm{M}$ showed that the fraction of trace metals in ion exchange position in this sediment was very low for $\mathrm{Cu}$ and absent for $\mathrm{Cd}$ and $\mathrm{Pb}$. This also suggests that the only immediate risk in Tripoli harbor sediments was related to the mobilization of $\mathrm{Cu}$.

\section{CONCLUSION}

The present work, conducted for the first time in Lebanese marine ports sediments, gave detailed information about trace metals $(\mathrm{Pb}, \mathrm{Cd}$ and $\mathrm{Cu}$ ) contamination and mobility in marine sediments of two ports in Lebanon: Beirut military port and Tripoli fishing port. This research activity was part of the CANA project: "Establishing Monitoring and Sustainable Development of the Lebanese Sea" aiming to evaluate the state of the environment of the Lebanese coastal zones. 
The analysis of $\mathrm{pH}$ and oxidation reduction potential levels in the studied port sediments showed clearly the impact of urban activities. In particular, the presence of sewage effluents discharges which contributed to the anoxia of the sediments. $\mathrm{Pb}, \mathrm{Cd}$ and $\mathrm{Cu}$ concentrations indicated the wide dispersion of the pollutants in the sediments of these two ports; the highest values were detected inside the ports, thus reflecting the negative impact of the anthropogenic sources (discharge of untreated sewage, solid waste, port activities, etc...). The study of the mobility of these trace metals in the presence of EDTA and $\mathrm{CaCl}_{2}$ showed that $\mathrm{Cd}$ was the most extracted by EDTA and subsequently represents the most environmental risk in the presence of such ligands. In the presence of $\mathrm{CaCl}_{2}, \mathrm{~Pb}$ was more easily mobilized in Beirut sediments and therefore represents the highest risk of mobilization to the water column and to living organisms. Knowing that $\mathrm{Cd}$ mobilization by $\mathrm{CaCl}_{2}$ can be highly limited by its chloro-complexe form in sea water (vanLoon \& Duffy, 2011).

Consequently, this study clearly showed that ports areas in Lebanon are certainly contaminated with $\mathrm{Pb}, \mathrm{Cd}$ and $\mathrm{Cu}$ and these metals can be mobilized especially in the presence of organic ligands. Following these findings, protective measures have to be taken while applying dredging operation and appropriate sediments remediation techniques should be applied.

\section{ACKNOWLEDGEMENT}

This work was supported by a research grant from the National Council for Scientific Research - Lebanon.

\section{REFERENCES}

Abi-Ghanem, C. 2008. Spéciation des trois éléments traces mercure, plomb et cadmium dans les sédiments marins des zones côtières libanaises. Thèse à l'institut des sciences et industries du vivant et de l'environnement (Agro Paris Tech), 310p.

Abi-Ghanem, C., Chiffoleau, J.F., Bermond, A., Nakhlé, K., Borschneck, D., Cossa D. 2009a. Lead and its Isotopes in the Sediment of three Sites of the Lebanese Coasts: Estimation of Contamination Sources. Applied Geochemistry, 631: 1-12.

Abi-Ghanem, C., Bermond, A., Besancon, S., Nakhlé, K., Khalaf, G., Rozuel, E. 2009b. Cd and $\mathrm{Pb}$ extractability with EDTA in sediments of three contrasted sites of the Lebanese coast. Journal Scientifique Libanais, 10(2): 33-48.

Abi-Ghanem, C., Nakhlé, K., Bermond, A., Chiffoleau, J.F., Borschneck, D., Cossa D. 2010. Mercury and methylmercury distribution in the sediments of three sites of the Lebanese coasts, Eastern Mediterranean. Archives of Environmental Chemistry, 60(3): 394-409.

Abi-Ghanem, C., Khalaf, G., Najjar, E. 2012. The distribution of lead, cadmium and vanadium in Lebanese coastal sediments and mussel species (Brachidontes variabilis). Journal of coastal research, 30 (5): 1074-1080.

Adamo, P., Arienzo, M., Imperato, M., Naimo, D., Nardi, G., Stanzione, D. 2005. Distribution and partition of heavy metals in surface and sub-surface sediments of Naples city port. Chemosphere, 66 (6): 800-810.

Ben Allal, L., Ammari, M., Frar, I., Azmani, A., Belmokhtar, N.D. 2011. Caractérisation et valorisation des sédiments de dragage des ports de Tanger et Larache (Maroc). Revue Paralia, 4(5) : 1-13. 
Bermond, A., Malenfant, C. 1990. Estimation des cations métalliques liés à la matière organique à l'aide des réactifs chimiques : approche cinétique. Science du Sol, 28 : 43-51.

Bermond, A., Varrault, G., Sappin-Didier, V., Mench, M. 2005. A kinetic approach to predict soil trace metal bioavailability: preliminary results. Plant and Soil, 275: 21-29.

Bisson, M., Houeix, N., Gay, G., Lacroix, G., Lefevre, J.P., Magaud, H., Migne, V., Morin, A., Tissot, S. 2005. Cuivre et ses dérivés. INERIS -DRC-02-25590-02DF54.doc Version $\mathrm{N}^{\circ} 1-5$-mars $05.66 \mathrm{p}$.

BRGM 2001. Caractérisation des sédiments en vue d'un projet de dragage. Étude réalisée dans le cadre de Service Public du BRGM 01LIT306.

Buccolieri, A., Buccolieri, G., Cardellicchio, N., Dell'Atti, A., Di Leo, A., Maci, A. 2006. Heavy metals in marine sediments of Taranto Gulf (Ionian Sea, Southern Italy). Marine Chemistry, 99: 227-235.

Burdige, J.D. 2006. Geochemistry of marine sediments. Princeton university press. Princeton and Oxford. $609 \mathrm{p}$.

Callender, E. 2003. Heavy metals in the environment - Historical trends, pp. 67-105. In: Treatise on geochemistry (eds. H.D. Holland and K.K. Turekian), vol. 9, Environmental geochemistry (ed. B.S. Lollar), Elsevier-Pergamon, Oxford.

Cantwell, M.G., Burgess, R.M., Kester, D.R. 2002. Release and phase partitioning of metals from anoxic estuarine sediments during periods of simulated resuspension. Environmental Science and Technology, 36: 5328-5334.

Chiffoleau, JF. 2001. La contamination métallique. In: IFREMER, editor, pp. 39.

Dalman, O., Demirak, A., Balci, A. 2006. Determination of heavy metals (Cd, $\mathrm{Pb})$ and trace elements $(\mathrm{Cu}, \mathrm{Zn})$ in sediments and fish of the Southeastern Aegean Sea (Turkey) by atomic absorption spectrometry. Food chemistry, 95(1): 157-162.

Fakhri, M. 2005. Interactions de deux sources continentales, naturelle et anthropogénique, sur les carctéristiques physico-chimiques et biologiques du milieu marin de Batroun au Liban Nord (Méditerranée Orientale). Thèse à l'Université de la Méditerranée (Aix Marseille II), 275p.

Fangueiro, D., Bermond, A., Santos, E., Crapuca, H., Duarte, A. 2005. Kinetic approach to heavy metal mobilization assessment in sediments: choose of kinetic equations and models to achieve maximum information. Talanta, 66(4): 844-857.

Fuller, C.C., Davis, J.A. 1987. Processes and kinetics of $\mathrm{Cd}^{2+}$ sorption by calcareous aquifer sand. Geochimica Cosmochimica Aqua, 51: 1491-1502.

Hamdoun, H., Baraud, F., Basset, B., Leleyter, L., Lemoine, M. 2010. Environmental impact of reused dredged sediment. Poster pour la conférence SARCLE 2010 (Sustainable Approaches to Remediation of Contaminanted Land in Europe) à Gent (Belgique).

Hieu Ho, H., Swennen, R., Cappuyns, V., Vassilieva, E., Van Gerven, T. and Van Tran, T. 2012. Potential release of selected trace elements ( $\mathrm{As}, \mathrm{Cd}, \mathrm{Cu}, \mathrm{Mn}, \mathrm{Pb}$ and $\mathrm{Zn}$ ) from sediments in Cam River-outh (Vietnam) under influence of $\mathrm{pH}$ and oxidation. Science of the Total Environment, 435-436: 487-498.

Houba, V.J.G., Novozamsky, I., Temminghoff, E.J.M. 1997. Soil and plant analysis. Part 5, Departement of Soil Science and Plant Nutrition, Wageningen Agricultural University, The Netherlands.

Huerta-Diaz, M.A., Delgadillo-Hinojosa, F., Hernandez-Ayon, M., Segovia-Zavala, J.A., Garcia-Esquivel, A., Lopez-Zarate, H., Siqueiros-Valencia, A., Galindo-Bect, S. 2008. Diagnosis of trace metal contamination in sediments: the example of Ensenada and El Sauzal, two harbors in Baja California, Mexico. Marine Environmental Research, 66: 345-358. 
Huntingford, E J., Turner, A. 2011. Trace metals in harbor and slipway sediments from the island of Malta, central Mediterranean. Marine Pollution Bulletin, 62: 1557-1561.

Jamali, M.K., Kazi, T.G., Arain, M.B., Afridi, H.I., Jalbani, N., Kandhro, G.A., Shah, A.Q., Baig, J.A. 2009. Speciation of heavy metals in untreated sewage sludge by using microwave assisted sequential extraction procedure. Journal of Hazardous Materials, 163(2-3): 1157-1164.

Kabata-Pendias, A., Pendias, H. 1992. Trace elements in soils and plants. 2d ed. CRC Press London.

Leleyter, L., Rousseau, C., Biree, L., Baraud, F. 2012. Comparison of EDTA, $\mathrm{HCl}$ and sequential extraction procedures, for selected metals $(\mathrm{Cu}, \mathrm{Mn}, \mathrm{Pb}, \mathrm{Zn})$, in soils, riverine and marine sediments. Journal of Geochemical Exploration, 116-117: 5159.

Li, X-D., Shen, Z.G., Wai, W.H.O., Li, Y.S. 2001. Chemical forms of $\mathrm{Pb}, \mathrm{Zn}$ and $\mathrm{Cu}$ in the sediment profiles of the Pearl River Estuary. Marine Pollution Bulletin, 42: 215223.

Loring, D.H., Rantala, R.T.T. 1990. Sediments and suspended particulate matter: total and partial methods of digestion. ICES Techniques in Marine Environmental Sciences, 9: $14 \mathrm{p}$.

Luoma, S.N. 1983. Bioavailability of trace metals to aquatic organisms: a review. Science of the total environment, $28: 1-22$.

Manouchehri, N. 2006. Contribution à l'étude de la disponibilité des éléments traces métalliques $(\mathrm{Pb}, \mathrm{Cu}, \mathrm{Cd})$ des sols à l'aide du réactif EDTA. Thèse à l'Université Paris 7, Denis Diderot, 216p.

Marrec, A., Proulhac, N. 2012. Caractérisation des sédiments du port de plaisance, port de Croisic. IDRA Environnement SAS. 35170 BRUZ, 59p.

Muller, G. 1979. Heavy metals in the sediment of the Rhine-changes seity. Umsch Wiss. Tech, 79: 778-783.

Mulligan, C.N., Yong, R.N., Gibbs, B.F. 2001. An evaluation of technologies for the heavy metal remediation of dredged sediment. Journal of Hazardous Materials, 85: 145163.

Nakhlé, K. 2003. Le mercure, le cadmium et le plomb dans les eaux littorales libanaises : apports et suivi au moyen de bioindicateurs quantitatifs (éponges, bivalves et gasteropodes). Thèse à l'Université Paris 7 Denis Diderot, 237p.

Nowak, B., Kari, F.G., Kruger, H.G. 2001. The remobilization of metals from iron oxides and sediments by metal-EDTA complexes. Water Air and Soil Pollution, 125: 243-257.

Paya-Perez, A., Sal, J., Mousty, F. 1993. Comparison of ICP-AES and ICP-MS for the analysis of trace elements in soil extracts. International Journal of Environmental Chemistry, 51: 223-230.

Picot, A. 2003. Intoxication de l'organisme par les métaux lourds et autres toxiques. Le mercure, le plomb et le cadmium trois métaux traces toxiques. Conférence ADNO, Paris.

Pueyo, M., Lopez-Sanchez, J.F., Rauret, G. 2004. Assessment of $\mathrm{CaCl}_{2}, \mathrm{NaNO}_{3}$ and $\mathrm{NH}_{4} \mathrm{NO}_{3}$ extraction procedures for the study of $\mathrm{Cd}, \mathrm{Cu}, \mathrm{Pb}$ and $\mathrm{Zn}$ extractability in contaminated soils. Analytica Chimica Acta, 504 : 217-226.

Rigaud, S., Radakovitch, O., Couture, R.-M., Deflandre, B., Cossa, D., Garnier, C., Garnier, J.-M. 2013. Mobility and fluxes of trace elements and nutrients at the sedimentwater interface of a lagoon under contrasting water column oxygenation conditions. Applied Geochemistry, 31: 35-51. 
Romano, E., Ausili, A., Zharova, N., Magno, M.C., Pavoni, B., Gabellini, M. 2004. Marine sediment contamination of an industrial site at Port of Bagnoli, Gulf of Naples, Southern Italy. Marine Pollution Bulletin, 49: 487-495.

Sahuquillo, A., Rogol, A., Rauret, G. 2003. Overview of the use of leaching/extraction tests for risk assessment of trace metals in contaminated soils and sediments. Trends in Analytical Chemistry, 22(3): 152-158.

Singh, N., Turner, A. 2009. Trace metals in antifouling paint particles and their heterogeneous contamination of coastal sediments. Marine Pollution Bulletin, 58: 559-564.

Tahchy, D. 2011. Contamination et mobilité du plomb et du cadmium dans les sédiments du port de plaisance de Jounieh. Mémoire de Master à USEK, Liban. 55p.

Tessier, E., Garnier, C., Mullot, J.-U., Lenoble, V., Arnaud, M., Raynaud, M., Mounier, S. 2011. Study of the spatial and historical distribution of sediment inorganic contamination in the Toulon bay (France). Marine Pollution Bulletin, 62: 20752086.

Turekian, K.K., Wedepohl, K.H. 1961. Distribution of the Elements in some major units of the Earth's crust. Geological Society of America Bulletin, 72: 175-192.

vanLoon, G.W., Duffy, S. 2010. Environmental chemistry, a global perspective. Third edition, Oxford.

Yuan, C.-G., Schi, J.B., He, B., Liu, J.F., Liang, L.N., Jiang, G.B. 2004. Speciation of heavy metals in marine sediments from the East China Sea by ICP-MS with sequential extraction. Environment International, 30(6): 769-783. 